\title{
HAMBATAN SISWA SMA DI BOYOLALI DALAM PELATIHAN PUBLIC SPEAKING
}

\author{
Fizzy Andriani, Wahyu Srisadono
}

\author{
Fakultas Ilmu Komunikasi Universitas Prof. Dr. Moestopo (Beragama) \\ fizzyandriani@dsn.moestopo.ac.id
}

Diajukan: 31-10-2017; Direview: 01-11-2017; Direvisi: 08-11-2017; Diterima: 12-12-2017

\begin{abstract}
The need in public speaking skills is increasing recently, including among high school students. In this case, high school students in Boyolali consider that public speaking training still new to them. Most of them have some fear and anxious doing Public Speaking. This research aims to see how the students do public speaking, what they feel, what are the obstacles, and how they are dealing with it. This is a descriptive qualitative research, through postpositivist paradigm. The object of this research is how students deal with Public Speaking training, by selecting some students as informants.
\end{abstract}

Keywords: Anxiety, students, public speaking

\begin{abstract}
Abstrak
Kebutuhan akan kemampuan public speaking semakin meningkat di masyarakat, termasuk dikalangan siswa SMA. Sementara sebagian besar siswa SMA di Boyolali masih menganggap pelatihan public speaking ini merupakan hal baru bagi mereka. Sehingga masih banyak diantara mereka yang mengalami ketakutan dan kecemasan pada saat diminta berbicara di depan umum. Peneliti ingin melihat bagaimana siswa SMA di Boyolali dalam menghadapi pelatihan public speaking, apa yang mereka rasakan, apa kendalanya, dan bagaimana mereka mengatasi kendala tersebut. Penelitian ini adalah penelitian deskriptif kualitatif dengan paradigm post-positivis. Objek dalam penelitian ini adalah bagaimana siswa SMA di Boyolali dalam melakukan pelatihan Public Speaking dengan memilih beberapa siswa sebagai informan.
\end{abstract}

Kata kunci: kecemasan, siswa, public speaking

\section{PENDAHULUAN}

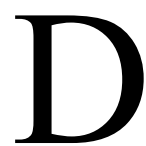
i era informasi saat ini, kemampuan berkomunikasi seseorang merupakan sesuatu hal yang sangat penting. Bahkan kemampuan tersebut juga sangat dibutuhkan untuk kalangan anak-anak dan remaja. Kemampuan komunikasi dikalangan anak-anak dan remaja bahkan dibutuhkan dalam interaksi mereka, termasuk pada saat mereka bercerita. Dengan kemampuan berkomunikasi yang baik, seseorang akan memiliki kesempatan yang luas untuk berkembang dengan cara menyampaikan ide-ide atau pemikiran mereka. Kemampuan berkomunikasi tersebut dapat membawa seseorang meraih impiannya. Namun, tidak banyak yang menyadari pentingnya pelatihan Public Speaking ini, terutama untuk anak-anak dan remaja. Kesadaran akan pentingnya pelatihan Public Speaking ini hanya terlihat di sekolah atau di kampus tertentu dan masih sedikit jumlahnya. Bahkan seringkali dikalangan dosen mengeluhkan kemampuan mahasiswa dalam melakukan presentasi tugas. Sementara didunia kerja saat ini hampir semua membutuhkan kemampuan Public Speaking yang tinggi.

Kecenderungan yang terjadi saat ini, banyak perusahaan yang menjadikan Public speaking sebagai salah satu kebutuhan perusahaan. Kebutuhan 
akan Public Speaking hampir disemua bidang, mencakup komunikasi eksternaldan komunikasi internal perusahaan. Hal ini menyebabkan semakin banyak perusahaan yang secara khusus mengirimkan para karyawannya untuk mengikuti pelatihanpelatihan public speaking di berbagai tempat. Bahkan tak sedikit perusahaan-perusahaan itu sendiri yang menjadi penyelenggara pelatihan public speaking secara in house di perusahaan mereka dengan mengundang para pakar public speakingsebagai narasumber pelatihan tersebut.

Kebutuhan yang semakin besar atas kemampuan public speaking ini, membuat tak sedikit perguruan tinggi yang memiliki fakultas/jurusan komunikasi memasukkan public speaking ke dalam kurikulum mereka. Tujuannya adalah agarketika para mahasiswa mereka lulus menjadi sarjana dan terjun di masyarakat, mereka akan mampu menyampaikan ide-idenya dengan keahlian berbicara yang baik. Namun kebutuhan akan kemampuan berbicara di depan umum tidak hanya dibutuhkan oleh para mahasiswa atau para pekerja. Kemampuan ini juga dibutuhkan oleh para siswa sekolah, mulai dari tingkat dasar hingga menengah. Dan mereka juga perlu mendapatkan pelatihan public speaking sejak dini. Pelatihan public speaking akan membuat mereka memiliki keberanian dan kemampuan untuk berbicara di depan umum, dimulai dari lingkungan kelasnya masing-masing.Untuk jangka pendek, pelatihan public speaking ini setidaknya akan membuat para siswa mampu menyampaikan presentasi di depan teman-temannya dan para guru, serta mampu berpidato di lingkungan sekolah di hadapan guru dan para orangtuanya. Untuk jangka menengah, ketika mereka melanjutkan pendidikan di perguruan tinggi, mereka akan memiliki kemampuan untuk mempertahankan skripsinya di depan sidang skripsi. Untuk jangka panjang, ketika tiba saatnya mereka mencari kerja, kemampuan public speaking ini sangat berguna dalam menghadapi wawancara-wawancara kerja. Tentu saja masih banyak-banyak manfaat-manfaat lainnya dari kemampuan public speaking ini untuk masa depan para siswa.

Pelatihan Public Speaking terhadap siswasiswa SMA di Boyolali tergolong masih jarang dilakukan. Sehingga tidak sedikit siswa-siswi SMA di Boyolali yang merasa ini adalah pelatihan pertama buat mereka. Mereka sebelumnya tidak menyadari pentingnya public speaking untuk masa depan mereka. Karena rata-rata mereka akan bekerja menjadi buruh-buruh pabrik selepas kelulusan mereka dari SMA, seperti rata-rata orang tua mereka. Kondisi ini sangatlah memprihatinkan. Padahal bukan tidak mungkin dengan kemampuan public speaking yang mereka miliki, akan membuat mereka mampu menyampaikan apa yang ada dalam benak mereka kepada orang lain, untuk kemudian diharapkan mereka mampu bertukar pikiran dan berbagi informasi dengan banyak orang. Dan tentu saja hal tersebut juga dapat meningkatkan bargaining power mereka di masyarakat.

Mengingat minimnya pengalaman siswa dalam melakukan public speaking, maka pelatihan yang dilakukan adalah pelatihan untuk kelompok pemula. Dimana tujuan utama pelatihan ini adalah untuk meningkatkan kepercayaan diri siswa agar berani tampil berbicara di depan orang banyak. Yang menjadi permasalahan penelitian ini adalah: apa yang dirasakan siswa SMA di Boyolali dalam implementasi pelatihan Public Speaking?; Apa kendala yang dihadapi siswa-siswi SMA di Boyolali dalam melakukan Public Speaking?: dan bagaimana mereka mengatasi kendala tersebut? Sementara yang menjadi tujuan penelitian adalah untuk melihat: Implementasi pelaksanaan Public Speaking terhadap siswa-siswi SMA di Boyolali, dan masalah yang dihadapi siswa-siswi SMA di Boyolali dalam melakukan Public Speaking

\section{LITERATUR DAN METODOLOGI}

Public speaking merupakan kemampuan, praktik, atau proses dalam melakukan pidato di depan banyak orang. Yang mendasari orang ingin memelajari public speaking menurut Prochnow (1987), adalah yang pertama public speaking dipelajari sebagai sebuah kebutuhan untuk berbicara dengan jelas dan fungsinya sangatlah besar untuk mendulang sukses dalam bisnis atau karir profesional lainnya. Alasan yang kedua adalah sebagai kesenangan semata, yang bisa dimaknai dengan kepuasan sang pembicara ketika ia berbicara di depan khalayak banyak sehingga mampu menggugah hati khalayak tersebut.

Terdapat beberapa perbedaan mendasar yang membedakan public speaking dan percakapan menurut Lucas (2004) yang dapat dijelaskan secara singkat, bahwa: Public speaking lebih terorganisasi dibandingkan dengan percakapan karena di dalamnya terdapat suatu proses persiapan dan batasan waktu. Sehingga, pelakunya harus benar-benar mempersiapkan 
secara matang.; Dalam public speaking bahasa yang digunakan lebih formal karena ditujukan ke banyak orang dan juga untuk maksud tertentu.; Dalam publik speaking diperlukan berbagai metode atau cara penyampaian.

Terdapat beberapa teknik yang umum digunakan dalam pelatihan public speaking. Berikut adalah teknik-teknik yang sering digunakan dikutip dari http://indosdm.com/public-speaking-pedomanberbicara-di-depan-publik diantaranya: Usahakan Anda terlihat oleh audiens. Usahakan Anda terlihat oleh audiens, dapat diartikan pembicaraharus tampil didepan atau ditempat yang dapat terlihat oleh audience. Tujuannya agar apa yang disampaikan oleh pembicara dapat menjadi perhatian audience.; Pastikan suara Anda terdengar oleh seluruh audiens. Sampaikan ide dengan volume suara yang didengar oleh seluruh audiens, pilih kata yang tepat, pelafalan yang jelas, dan intonasi yang sesuai. Gunakan suara lantang untuk semangat, komando dan perintah. Suara lirih untuk hal penting. Variasikan kecepatan bicara untuk meningkatkan kepentingan pesan Anda. Variasikan dengan jeda yang sering, irama yang mantap, dan kalimat yang pendek.; Lakukan kontak mata. Tatapan langsung ke audience dapat memberikan dampak audience merasa diajak bicara. Hal tersebut akan membuat audience memperhatikan pembicaraan kita.; Katakan dengan wajah dan Bahasa tubuh. Be Natural: jangan diam atau terlihat kaku. Gunakan gerakan tangan, langkah kaki, untuk memperkuat arti. Lakukan sedikit gerak untuk audiens, cukup ekspresi wajah dan gerakan tangan. Jika audiens banyak, perbanyak gerak. Untuk menjelaskan konsep abstrak, kurangi gerak dan bicaralah perlahan. Untuk topik ringan, perbanyak gerak.; Berbicara dan Menutup Pembicaraan dengan Baik. Simpulkan pembicaraan. Akhiri dengan mengutip kata-kata bijak yang sesuai dengan tema Anda. Buat pertanyaan yang dramatis. Jika ide Anda berupa ajakan, beri semangat melakukannya.

Namun dalam pelaksanaannya, public speaking dapat menimbulkan rasa cemas, takut dan kepanikan bagi sang komunikator, terutama komunikator pemula. Kecemasan berkomunikasi menurut Jalaluddin Rakhmat (2000) adalah batu sandungan yang besar bagi seorang pembicara.
Kecemasan atau anxiety adalah:

"Anxiety is defined as a state of uneasiness and apprehension or fear caused by the anticipation of something threatening. Public speaking anxiety is very common among both college students and the general population. Persons with public speaking anxiety often avoid anxiety-producing social or performance situations, but when unavoidable, these situations are endured with feeling of intense anxiety and distress. Also, anticipatory anxiety frequently occurs as an individual imagines the situation in advance of the actual experience (e.g., worrying each day about a presentationto be given in a class several weeks in the future).Although individuals with these types ofanxious responses often recognize that theirfear is excessive and/or unreasonable, they areunable, without assistance, to change their responsesin these situations.Individuals with public speaking anxiety most often experience a variety of symptoms in a public speaking situation, including palpitations, sweating, gastrointestinal discomfort, diarrhea, muscle tension, and confusion." (North \& Rives; 2001).

Berdasarkan statemen diatas dapat disimpulkan, bahwa bagi sebagian orang, melakukan public speaking itu adalah hal yang menakutkan, dan dapat menciptakan respon yang beraneka ragam mulai dari kekhawatiran dalam menghadapinya, berkeringan dingin, tidak dapat bicara, bahkan sampai diare dan gangguan pada lambung. Dimana semua hal tersebut terjadi akibat stress yang berlebihan dalam menghadapi public speaking. llmu retorika pada awalnya dikembangkan di Yunani berkaitan dengan ilmu tentang Seni Berbicara (Techne Rhetorike). Aristoteles merupakan orang pertama yang memberikan kontribusi terhadap komunikasipublik, khususnya retorika. Teori retorika berpusat pada pemikiran mengenai retorika yang disebutkan oleh Aristoteles sebagai alat persuasi yang tersedia.

Dalam bukunya, Jalaludin Rakhmat mengatakan bahwa setiap gerakan didunia ini dikembangkan oleh ahli-ahli pidato dan bukan oleh jago-jago 
tulisan. (Rakhmat, 2008:1). Dalam bukunya Retorika Modern: Pendekatan Praktis, Jalaludin Rakhmat membagi pidato ke dalam beberapa jenis, yaitu impromptu, manuskrip, memoriter dan ekstempore. (Rakhmat, 2008). Jalaludin Rakhmat juga menyebutkan berbagai ketenruan dalam memilih topic yang baik, agar para pendengar pun merasa tertarik untuk mendengar pidato yang kita bawakan, diantaranya: Topik harus sesuai dengan latar belakang pengetahuan anda, Topik harus menarik minat anda, Topik harus menarik minat pendengar, Topik harus sesuai dengan pengetahuan pendengar, Topik harus jelas ruang-lingkup dan pembahasannya, Topik harus sesuai dengan waktu dan situasi, Topik harus dapat ditunjang dengan bahasa lain.

Sementara, dalam menyampaikan pidato Jalaludin Rakhmat juga mengatakan terdapat beberapa prinsip,yaitu: Komunikasi tatap muka, yang bersifat dua arah. Walaupun pembicara lebih banyak mendominasi pembicaraan, ia harus "mendengarkan" pesan-pesan yang disampaikan para pendengarnya (baik berupa kata-kata tau bukan kata-kata); Pidato, seperti teater, sangat bergantung pada acting. Salah satu unsur acting adalah olah vocal. Dalam buku ini ada toga hal yang harus diperhatikan dalam olah vocal: kejelasan, keragaman, dan ritma.; Gerakan tubuh pada saat berpidato akan membuat audiensikut bergerak. Mereka akan ikut merasakan apa yang anda rasakan. Bagi komunikator, gerak fisik dapat menyalurkan energy tambah dalam tubuhnya. Dengan demikian, ia mengurangi kecemasan komunikator dan meningkatkan kepercayaan diri.

Riset kualitatif bertujuan untuk menjelaskan suatu fenomena sedalam-dalamnya melalui pengumpulan data yang sedalam-dalamnya (Kriyantono, 2008). Kaitannya dengan Implementasi Pelatihan Public Speaking pada siswa-siswi SMAN 1 Boyolali yang diangkat dalam penelitian ini, peneliti menggunakan metode penelitian studi kasus dimana secara khusus peneliti melihat bagaimana siswa dapat mengembangkan kemampuan Public Speaking mereka setelah pelatihan. Studi kasus adalah studi mengenai kekhususan dan kompleksitas suatu kasus tunggal dan berusaha untuk mengerti kasus tersebut dalam konteks situasi, dan waktu tertentu. (Semiawan, 2010). Metode kualitatif digunakan untuk mendapatkan data yang mendalam, suatu data yang mengandung makna. Makna adalah data yang sebenarnya, data yang pasti yang merupakan suatu nilai dibalik data yang tampak. (Sugiyono, 2007:9)

Denzin dan Lincoln (1987) dalam Moleong 2001 menyatakan bahwa penelitian kualitatif adalah penelitian yang menggunakan latar alamiah, dengan maksud menafsirkan fenomena yang terjadi dan dilakukan dengan jalan melibatkan berbagai metode yang ada. Dari segi pengertian ini, para penulis masih tetap mempersoalkan latar alamiah denganmaksud agarhasilnya dapat digunakan untuk menafsirkan fenomena dan yang dimanfaatkan untuk penelitian kualitatif adalah berbagai macam metode penelitian. Dalam penelitian kualitatif ini metode yang digunakan adalah pemanfaatan dokumen. Penelitian kualitatif tidak mencari ataupun menjelaskan suatu hubungan dan tidak menguji atau membuat suatu hipotesis yang segi proses dari pada hasil. Hal ini dikarenakan oleh hubungan bagian-bagian yang sedang diteliti jauh lebih jelas apabila diamati dalam proses. Di dalam penyusunan desain juga dilaksanakan secara terusmenerus disesuaikan dengan kenyataan lapangan. Jadi, tidak menggunakan desain yang telah disusun secara ketat dan kaku sehingga tidak dapat diubah lagi. (Moleong, 2001:7).

Penelitian ini menggunakan paradigma postpositivis, dimana paradigm ini bersifat naturalistik karena penelitiannya dilakukan pada kondisi yang alamiah (natural setting). Analisis data yang dilakukan bersifat induktif berdasarkan faktafakta yang ditemukan dilapangan dan kemudian dikonstruksikan menjadi hipotesis atau teori. (Sugiyono, 2007:7). Post-positivis ini merupakan paradigma yang ingin memperbaiki kelemahankelemahan Positivisme yang hanya mengandalkan kemampuan pengamatan langsung terhadap objek yang diteliti. Secara ontologi aliran ini bersifat critical realism yang memandang bahwa realitas memang ada dalam kenyataan sesuai dengan hukum alam, tetapi suatu hal, yang mustahil bila suatu realitas dapat dilihat secara benar oleh manusia (peneliti). Oleh karena itu secara 
metodologi pendekatan eksperimental melalui metode triangulation yaitu penggunaan bermacammacam metode, sumber data, peneliti dan teori.

Selanjutnya dijelaskan secara epistomologis hubungan antara pengamat atau peneliti dengan objek atau realitas yang diteliti tidaklah bisa dipisahkan, tidak seperti yang diusulkan aliran Positivisme. Aliran ini menyatakan suatu hal yang tidak mungkin mencapai atau melihat kebenaran apabila pengamat berdiri di belakang layar tanpa ikut terlibat dengan objek secara langsung. Oleh karena itu, hubungan antara pengamat dengan objek harus bersifat interaktif, dengan catatan bahwa pengamat harus bersifat senetral mungkin, sehingga tingkat subjektivitas dapat dikurangi secara minimal (Salim, 2001:40). Objek dalam penelitian ini adalah bagaimana pelaksanaan program pelatihan Public Speaking yang dilakukan kepada Siswa-siswi SMA di Boyolali dengan beberapa siswa yang dipilih sebagai narasumber. Siswa dipilih berdasarkan kesediaan untuk diwawancara, ikut dalam pelatihan public speaking, ikut tampil berbicara di depanpada saat pelatihan, dan dinilai cukup berhasil pada saat tampil, walaupun terlihat tidak berani diawal, dan berasal dari 3 SMA penyelenggara yaitu SMAN1 Boyolali, SMA Simo Boyolali, SMAN 1 Karanggede. Dimana dari masing-masing sekolah dipilih 2 orang siswa yang sesuai dengan kriteria tersebut diatas. Dari kriteria tersebut peneliti memilih 6 orang siswa yang menjadi narasumber penelitian.

Teknik pengumpulan data adalah data teknik atau cara-cara yang dapat digunakan peneliti untuk mengumpulkan data (Kriyantono, 2008). Dalam penelitian ini metode pengumpulan data yang digunakan adalah observasi (field observations), wawancara mendalam, dan studi dokumen. Teknik analisis data merupakan sebuah proses mengorganisasikan dan megurutkan data ke dalam pola, kategori, dan satuan uraian dasar sehingga dapat ditemukan tema serta dirumuskan sebuah hipotesis kerja seperti yang disarankan oleh data (Kriyantono, 2008).

\section{TEMUAN DAN DISKUSI}

Pelatihan Public Speaking ini dilakukan selama 3 hari disekolah yang berbeda, yaitu SMAN 1 Boyolali, SMA Simo Boyolali, SMAN 1 Karanggede. Sekolah-sekolah tersebut dipilih karena menjadi penyelenggara pelatihan Public Speaking ini. Dalam pelaksanaanya, pelatihan dilakukan dengan cara pemberian materi awal yang dilakukan langsung oleh peneliti. Setelah materi dirasa cukup, masuk ke sesi berikutnya, yaitu meminta siswa-siswi untuk menentukan dan mempersiapkan materi yang ingin mereka sampaikan ke hadapan teman-temannya. Materi ini tidak diberi batasan tema. Hal ini dilakukan demi mempermudah siswa untuk menyampaikan materi yang sangat mereka sukai dan pahami. Jika persiapan materi setiap siswa telah selesai, dilanjutkan pada sesi berikutnya, dimana satupersatu siswa-siswi maju ke depan secara bergiliran sesuai kesiapan masing-masing siswa-siswi tersebut. Sesi ini yang paling menegangkan buat para siswa-siswi setiap sekolah tersebut. Untuk meminimalisir ketegangan dan rasa takut yang melanda siswa-siswi, giliran mereka ditentukan berdasarkan kesiapan. Hal ini membuat siswasiswi yang memiliki kepercayaan tinggi dan siap dengan materinya maju terlebih dahulu, dan dapat menjadi contoh termasuk menambah rasa percaya diri-teman-teman lainnya. Pemaparan berikut merupakan beberapa hasil temuan di lapangan:

Dalam hal ini, karena pelatihan dilakukan dikelas, dengan jumlah siswa yang hadir sekitar 25 anak perkelas. Dalam pelaksanaannya semua peserta termasuk narasumber memang diminta untuk tampil di depan kelas. Sehingga hal ini sangat memungkinkan semua peserta terlihat oleh audience saat melakukan public speaking tersebut. Walaupun demikian, cukup banyak siswa yang merasa kurang percaya diri untuk tampil didepan kelas. Salah satunya adalah M. Filki N. dari SMAN 1 Karanggede. Menurut Fikli, dia tidak terbiasa tampil didepan. Dia tidak masalah jika harus bercerita dengan teman-temannya. Namun tampil sendiri didepan, terutama dihadapan orang-orang yang tidak dikenalnya secara dekat merupakan hal yang berbeda. Apa yang dirasakan Filki juga dirasakan narasumber lainnya, seperti Nafisa Salsabilah dari SMAN 1 SIMO. Nafisa mengatakan bahwa dia sangat tidak percaya diri 
pada saat harus tampil didepan. Sampai meminta untuk berbicara dari bangku duduknya.

Tidak semua siswa bias dengan mudah tampil didepan orang lain. Butuh waktu untuk membujuk para siswa seperti ini sampai mereka bersedia tampil didepan kelas. Namun demikian, Filki dan Nafisa cukup berhasil mengatasi permasalahannya. Terbukti pada saat dirinya diminta untuk maju, baik Filki maupun Nafisa minta waktu hanya sebentar saja, namun setelah didepan keduanya dapat bercerita cukup panjang dalam waktu kurang lebih 10 menit. Hal ini menunjukkan bahwa ketidakpercayaan diri saat tampil di depan umum hanya permasalahan sesaat yang dirasakan oleh siswa. Namun akan mampu mereka atasi nantinya.

Banyak siswa yang karena tidak terbiasa untuk tampil di muka umum merasa grogi, sehingga suara mereka sangat pelan dan kurang terdengar. Dan bahkan ada beberapa diantaranya sampai terbatabata dan banyak terdiam beberapa saat. Dalam kondisi seperti ini trainer berusaha memancing mereka berbicara dengan bertanya tentang materi yang mereka sampaikan. Atau bahkan ada siswa yang tidak tahu harus berbicara apa didepan, trainer berupaya mengajuka pertanyaan terkait halhal yang disukai siswa, untuk kemudian bertanya tentang hal tersebut. Juga meminta audience untuk ikut bertanya terkait materi yang disampaikan. Sehingga siswa tersebut berbicara terus untuk menjawab pertanyaan yang diajukan. Hal ini terjadi pada salah satu siwa yaitu Faiz Nugroho Putro dari SMAN 1 SIMO. Faiz sangat sulit diminta berbicara didepan. Suaranya tersendat-sendat, dan terkadang seperti berpikir 'harus bicara apalagi'.

Apa yang terjadi pada Faiz cukup sering terjadi. Trainer memang meminta siswa untuk memilih materi yang mereka pahami dengan baik, sehingga memudahkan mereka untuk bercerita di depan kelas. Namun rasa grogi membuat mereka lupa akan materi yang telah mereka siapkan tersebut. Hal ini juga terjadi pada Alma Kamila Khanza dari SMAN 1 Boyolali. Walaupun suara Alma terdengar cukup jelas, namun Alma sering terbata-bata dalam penyampaiannya. Sama seperti yang dialami Faiz. Alma tiba-tiba lupa akan materinya pada saat dia sudah tampil didepan. Rasa groginya membuatnya mengalami kesulitan untuk mengingat materi presentasinya. Untuk mengatasi hal ini trainer kembali bertanya tentang hal-hal yang disukai siswa seperti hobi dan lain-lain. Dan kemudian meminta siswa bercerita tentang hal tersebut. Ternyata hal tersebut sangat membantu siswa dalam mengembalikan rasa kepercayaan dirinya. Hal ini menunjukan bahwa materi yang sangat mereka sukai dan pahami akan sangat membantu mereka dalam menyampaikan materi dengan lancar dan jelas. Kesenangan Alma terhadap One Direction berhasil membantu Alma menemukan kepercayaan dirinya saat harus berbicara didepan kelas. Suaranya yang terbata-bata diawal berubah menjadi lancar saat bercerita tentang boyband group kesayangannya tersebut.

Kontak mata dilakukan dalam upaya membangun hubungan dengan audience, agar audience dapat merasakan apa yang kita ceritakan. Namun bagi pemula, dalam pelaksanaannya setiap orang bisa berbeda-beda. Ada siswa yang memiliki kepercayaan diri yang tinggi merasa lebih nyaman jika ia melakukan kontak mata satu persatu terhadap audience-nya. Hal ini terjadi pada Bernadeta Ruthia K.A dari SMAN 1 Boyolali. Bagi Bernadeta, menatap audience-nya secara bergantian justru menimbulkan kenyamanan bagi dirinya untuk terus bercerita. Namun hal ini tidak dirasakan oleh Filki dan Faiz. Keduanya justru merasa belum nyaman ketika harus melakukan kontak mata dengan audience-nya. Sedikit berbeda dengan Faiz, Filki sedikit lebih bisa melakukan kontak mata walaupun hanya sebentar. Bagi Filki, semakin sering dia melakukan kontak mata justru akan mengganggu konsentrasinya. Sehingga Filki memilih untuk meminimalisir terjadinya kontak mata.

Berdasarkan hal diatas, dapat disimpulkan bahwa setiap siswa memiliki cara tersendiri untuk mengatasi rasa groginya untuk tampil berbicara didepan umum. Dan masalah tatap muka dengan audience merupakan salah satu hal yang memberikan dampak berbeda yang dirasakan siswa dalam melakukan public speaking. Mengingat para siswa ini masih pemula dalam hal public speaking, hal ini masih dianggap wajar. Namun diharapkan akan semakin membaik nantinya. Apa yang dirasakan seseorang dan apa yang ada 
dipikiran seseorang pada saat melakukan Public speaking akan dapat dirasakan oleh audience-nya melaui ekspresi wajah dan Bahasa tubuh presenter. Namun bagi pemula tidaklah mudah bagi mereka untuk mengontrol ekspresi dan Bahasa tubuh mereka. Ekspresi dan Bahasa tubuh yang keluar dari mereka masih sangat jelas menggambarkan perasaan mereka yang grogi dan belum terbiasa. Seperti yang terjadi pada Nafisa yang pada saat menyampaikan materinya terkadang terlihat menunduk dan sering melakukan gerakan tubuh berulang kekiri dan kekanan. Namun masalah ini terlihat mampu diatasi dengan lebih baik oleh Bernadeta dan Nurul Azizah Almawiroh dari SMAN 1 Karanggede. Kedua siswa terlihat mampu tampil dengan ekspresi yang lebih rileks dibanding siswa lainnya. Bahasa tubuh mereka juga sangat minim menunjukan gerakan berulang yang menggambarkan ketidaknyamanan.

Hal yang sama juga terjadi pada Alma. Alma bercerita tentang One Direction dengan mata berbinar-binar menunjukan kesukaannya, serta Azizah yang terlihat begitu nyaman menceritakan gerakan-gerakan tarinya. Bahkan Azizah juga terlihat tidak malu-malu untuk memberikan contoh gerakan tarian yang menjadi favoritnya. Dari jawaban mereka, menunjukan bahwa semakin mereka merasa menyatu dengan materi yang mereka bawa, semakin mereka merasa nyaman. Dan semakin mereka merasa nyaman, semakin baik pula ekspresi wajah dan Bahasa tubuh mereka pada saat melakukan public speaking.

Dari keenam siswa, semua siswa secara umum berhasil menyampaikan materinya setelah mereka menemukan materi yang tepat untuk mereka sampaikan didepan kelas. Walaupun dari segi Bahasa belum sepenuhnya menggunakan Bahasa yang formal. Karena sebagai pemula, mereka merasa lebih nyaman menggunakan bahasa seharihari. Namun untuk kondisi tertentu, penggunaan bahasa ini bisa disesuaikan dengan materi dan audience yang mereka hadapi. Walaupun bukan Bahasa formal namun disampaikan dengan baik, maka pesannya dapat diterima dengan baik. Hal ini terlihat pada saat Bernadeta melakukan stand-up comedy sebagai materinya. Mengingat materi Bernadeta adalah stand-up comedy dengan audience remaja, penggunaan Bahasa yang formal justru akan menghambat penyampaian materi. Walaupun dengan Bahasa non-formal, namun Bernadeta tetap mampu menyampaikan humornya dengan baik tanpa menyinggung atau menyudutkan pihak-pihak tertentu.

Namun, selain Bernadeta, semua narasumber dan hampir sebagian besar siswa yang ikut dalam pelatihan public speaking ini kurang begitu baik dalam menutup pembicaraannya. Rata-rata materi mereka belum tersampaikan dengan sempurna, dan mereka langsung menutupnya dengan kata-kata 'iya sudah', 'itu aja', 'terimakasih'. Sehingga materi agak sedikit menggantung. Namun Bernadeta berhasil menyelesaikan public speakingnya dengan baik.Dan keberhasilan Bernadeta menutup stand-up comedy-nya terlihat dengan respon teman-temannya yang tertawa sampai riuh bertepuk tangan.

Berdasarkan hasil analisa diatas, pelaksanaan pelatihan public speaking terhadap siswa-siswi SMA di Boyolali yang digunakan adalah bentuk pelatihan dasar saja, yang meliputi melatih keberanian siswa-siswi untuk tampil didepan kelas agar terlihat oleh seluruh audience, melatih keberanian siswa-siswi untuk berbicara dengan suara yang dapat terdengar jelas oleh seluruh audience, melatih keberanian siswa-siswi untuk berbicara sambal menatap para audience-nya secara bergantian, melatih para siswa-siswi untuk mampu mengontrol ekspresi dan Bahasa tubuh mereka pada saat melakukan public speaking, dan terakhir, melatih siswa-siswi untuk mampu berbicara dengan dengan baik dan benar serta menutup pembicaraan dengan menarik.

Dalam tahapan melatih keberanian siswasiswi tampil didepan kelas agar dirinya terlihat oleh seluruh audience pada awalnya agak sulit, karena mereka masih merasa malu jika mereka melakukan kesalahan dihadapan teman-temannya. Sehingga pada tahap ini trainer bisa meminta siapa saja yang berani tampil lebih dahulu, dan mengijinkan mereka untuk berbicara mengenai hal apa saja yang mereka sukai dan pahami. Trainer juga tidak memberikan batasan waktu kepada siswa. Setelah siswa pertama maju ke depan dan bercerita kemudian mengalami hambatan seperti 
tidak tahu akan berbicara apa lagi, trainer harus berusaha mencairkan suasana dengan sedikit memberikan pertanyaan ringan terkait materi yang dibawa siswa, dan diyakini pertanyaan tersebut akan mampu dijawab siswa dan membuat siswa dapat bercerita lebih banyak lagi. Melibatkan siswa lain untuk bertanya juga dapat dilakukan. Jika suasana semakin mencair, siswa yang tampil di depan akan mulai merasa rileks dan ceritanya pun mengalir lebih lancar. Keberhasilan siswa yang tampil pertama ini akan memberikan contoh pada teman-temannya, sehingga mereka dapat lebih berani maju ke depan.

Hambatan yang mereka rasakan adalah rasa takut salah dan tidak percaya diri. Sebagian besar siswa akhirnya dapat diminta maju ke depan, walaupun beberapa diantaranya butuh sedikit bujukan. Setelah mereka selesai melakukan public speaking, mereka mengatakan sangat takut diawal, namun setelah berbicara didepan lama-lama mereka menjadi rileks. Untuk tahap melatih keberanian siswa-siswi untuk berbicara dengan suara yang dapat terdengar jelas oleh seluruh audience juga hampir sama dengan tahap sebelumnya. Cukup banyak siswa masih kurang berani untuk bercerita dengan suara lantang dan jelas terdengar. Dan banyak juga diantara mereka yang bercerita dengan terbata-bata, bahkan beberapakali terdiam saat tengah melakukan public speaking. Saat mereka baru mencoba untuk tampil didepan, rasa tidak percaya diri membuat mereka berbicara dengan suara pelan. Walaupun cukup banyak diantara mereka yang sudah berani berbicara dengan suara yang jelas terdengar. Namun dikarenakan ruangan cukup kecil dan jumlah siswa perkelas hanya sedikit, masalah suara yang pelan ini sedikit dapat teratasi.

Mereka mengungkapkan bahwa rasa grogi dan ketakutan mereka membuat mereka lupa akan materi yang sebelumnya telah mereka persiapkan. Mereka mengungkapkan bahwa materi yang telah mereka persiapkan adalah materi yang mereka pahami, namun pada saat berada di depan, mereka merasa seperti tidak tahu apalagi yang harus mereka sampaikan karena semuanya hilang dibenak mereka. Untuk mengatasi hal ini, suasana bisa dibuat lebih cair dengan mengajukan pertanyaan ringan maupun dengan sedikit bercanda, kemudian meminta mereka sedikit menambah volume suaranya. Pertanyaan-pertanyaan yang dapat diajukan biasanya seputar diri mereka, seperti hobi mereka apa, atau aktivitas yang mereka sukai atau sering mereka lakukan. Pertanyaan-pertanyaan tersebut mampu membuat mereka lebih rileks dan kemudian dapat melanjutkan cerita mereka lebih lancar.

Namun permasalahan suara dan kalimat yang terbata-bata ini lebih banyak terjadi pada awalawal sesi setiap harinya. Semakin lama, mereka semakin banyak melihat teman-temannya yang tampil, semakin mereka merasa rileks. Tak hanya itu, suasana kelaspun terasa semakin santai. Hal ini terlihat dari bagaimana temanteman dari siswa yang tampil bahkan sudah mulai mencoba membantu teman mereka agar lebih rileks, baik dengan memberikan respon positif yang menunjukan mereka tertarik dengan materinya, juga dengan sedikit menimpali dalam bentuk bercanda. Hal ini terlihat sangat mampu mengangkat rasa percaya diri siswa yang sedang melakukan public speaking.

Sementara pada tahap melatih keberanian siswa-siswi untuk berbicara sambil menatap para audience-nya, sangat sedikit siswa yang mampu melakukannya. Sebagian besar siswa belum memiliki keberanian untuk berbicara sambil menatap audience. Mereka cenderung memilih salah satu titik yang menjadi focus pandangan mereka. Titik yang menjadi focus perhatian mereka bisa tembok belakang kelas, luar ruangan, sisi bawah atau atas ruang kelas, meja kelas atau bahkan berpindah-pindah. Mereka, sebagian besar, berusaha menghindari tatapan audience. Namun ini lebih banyak hanya terjadi di awal-awal mereka memulai tampil untuk public speaking. Karena setelah beberapa menit, saat mereka mulai menemukan titik nyamannya, mereka sedikit demi sedikit mulai berani mencoba menatap audiencenya. Walaupun terkadang harus diingatkan kembali. Namun masih cukup banyak diantara mereka yang pada saat diingatkan untuk mulai menatap audience-nya, mereka langsung mendadak lupa akan materinya, bicaranya mulai terbata-bata, dan akhirnya mereka kembali menghindar untuk 
menatap audience-nya.

Kondisi ini menggambarkan bagaimana rasa percaya diri mereka masih belum keluar. Bagaimana public speaking masih menjadi suatu hal yang menakutkan buat mereka. Namun sebagai seorang pemula, hal ini tidak terlalu masalah. Namun penting untuk menjadi perhatian, untuk terus mengaktifkan siswa dalam melakukan public speaking. Sehingga mereka semakin terbiasa dengan public speaking, dan nantinya diharapkan hal-hal seperti ini semakin lama bisa diminimalisir. Untuk tahap melatih ekspresi dan Bahasa tubuh mereka pada saat melakukan public speaking, menunjukan hal yang sama dengan kontak mata. Mereka masih sangat kesulitan untuk menghilangkan ekspresi panik dan ketakutan di wajah mereka. Dalam berbicara mereka masih terlihat juga ekspresi mengingat dan menghafal, termasuk ekspresi berpikir. Ekspresi tersebut cukup tergambar jelas, sehingga dapat dirasakan oleh audiensnya.

Hal serupa juga terlihat pada bahasa tubuh mereka. Mereka banyak melakukan gerakan berulang, seperti gerakan ke kiri-ke kanan, gerakan memainkan jari atau rambut, memegang rok dan celana pada saat presentasi, menunduk, dan juga meletakkan tangannya dibelakang. Semua yang mereka lakukan tersebut juga menggambarkan rasa tidak nyaman yang muncul dalam diri mereka. Gerakan-gerakan tersebut seperti upaya mereka untuk menenangkan dan meminimalisir rasa tidak nyaman yang mereka rasakan. Semua bentuk ketidaknyamanan tersebut terjadi pada semua siswa-siswa, terutama diawal penampilan mereka. Menjelang akhir, beberapa diantaranya mulai menemukan kenyamanannya sehingga ekspresi dan bahasa tubuh seperti diatas mulai berkurang. Namun tetap sangat minim.

Dan terakhir, tahap melatih siswa-siswi untuk mampu berbicara dengan dengan baik dan benar serta menutup pembicaraan dengan menarik. Pada tahap ini tidak banyak juga siswa yang mampu melakukannya terutama jika dikaitkan dengan penggunaan Bahasa formal. Hampir seluruh siswa tetap menggunakan baha yang tidak formal, namun masih termasuk Bahasa yang baik, tepat, dan santun. Dan mengingat ini adalah pelatihan bagi pemula, hal tersebut masih dapat diterima, dengan harapan nantinya mereka akan berkembang dalam pelaksanaannya menjadi lebih baik.

\section{SIMPULAN}

Pelaksanaan pelatihan public speaking terhadap siswa-siswi SMA di Boyolali yang digunakan masih merupakan bentuk pelatihan dasar saja, yang meliputi melatih keberanian siswa-siswi untuk tampil didepan kelas agar terlihat oleh seluruh audience, melatih keberanian siswa-siswi untuk berbicara dengan suara yang dapat terdengar jelas oleh seluruh audience, melatih keberanian siswa-siswi untuk berbicara sambal menatap para audience-nya secara bergantian, melatih para siswa-siswi untuk mampu mengontrol ekspresi dan Bahasa tubuh mereka pada saat melakukan public speaking, dan terakhir, melatih siswa-siswi untuk mampu berbicara dengan dengan baik dan benar serta menutup pembicaraan dengan menarik. Namun dalam pelaksanaanya banyak dilakukan penyesuaian-penyesuaian, mengingat para siswa masih pemula dalam melakukan public speaking. Sehingga yang menjadi perhatian utama dalam pelatihan ini adalah bagaimana membuat mereka berani mencoba setiap tahap pelatihan.

Kendala yang dihadapi para siswa adalah, mereka masih merasa grogi dan tidak percaya diri untuk melakukan public speaking. Rasa takut salah, malu ditertawakan, tidak tahu mau berbicara apa merupakan perasaan yang mayoritas dialami siswa dalam pelatihan ini. Namun mengingat mereka baru pemula, hal ini bisa diterima. Rasa takut dan tidak percaya diri yang mereka rasakan bisa diatasi jika trainer tidak bersifat menekan mereka.

Dalam pelaksanaanya, pelatihan bagi pemula sebaiknya dibuat dalam suasana yang tidak kaku. Hal ini diharapkan akan mengurangi rasa takut dan grogi pada diri siswa-siswi. Walaupun public speaking seharusnya dilakukan dalam Bahasa yang formal, namun mengingat pelatihan untuk pemula ini lebih mengutamakan membuat mereka berani berbicara didepan dulu, penggunaan Bahasa formal bisa menyesuaikan. Karena jika dipaksakan, akan membuat mereka semakin tidak nyaman. Mengingat pentingnya kemampuan public speaking bagia setiap orang, penting untuk 
setiap sekolah secara rutin melakukannya terhadap siswa mereka sejak dini. Sehingga saat mereka dewasa, mereka sudah terbiasa melakukannya dan tidak lagi mengalami rasa panic. Hal ini tentu diharapkan akan berdampak positif terhadap masa depan mereka.

\section{DAFTAR PUSTAKA}

Cresswell, John W. 2009. Research design qualitative research. Terjemahan: Dariyatno, dkk. Yogyakarta: Pustaka Pelajar

Kriyanto, Rachmat. 2008. Riset Komunikasi. Malang: Kencana

Lucas, Stephen E. 2004. The Art of public Speaking. Eight Edition. New York: McGraw-Hill.

Moleong, Lexy. 2001. Metodologi Penelitian Kualitatif. Bandung. Remaja Rosda Karya.

Morissan. 2013. Teori Komunikasi Individu Hingga Massa. Jakarta: Kencana Prenada Media Group.

North, M., \& Rives, J. 2001. Virtual Reality Therapy in Aid of Public Speaking. International Journal of Virtual Reality 3:2-7.

Pace, R. Wayne \& Faules, Don F. 2000. Komunikas
Organisasi: $\quad$ Strategi meninggkatkan kinerja perusahaan. Bandung: PT Remaja Rosdakarya.

Prochnow, Herbert V. 1987, Penuntun menuju sukses dalam berpidato, Bandung: CV Pionir

Rakhmat, Jalaludin. 1999. Penelitian Komunikasi. Bandung: Remaja Rosdakarya.

Rakhmat, Jalaludin. 2008. Retorika Modern: Pendekatan Praktis. Bandung: PT Remaja Rosdakarya

Salim, Agus. 2001. Teori dan Paradigma Penelitian Sosial. Yogyakarta: Tiara Wacana

Sendjaja, S. Djuarsa. 2004. Pengantar Ilmu Komunikasi, Jakarta: Universitas Terbuka.

Semiawan, Conny R. 2010. Metode Penelitian Kualitatif. Jakarta: Grasindo.

Sugiyono, 2007. Metode Penelitian Kuantitatif, Kualitatif dan $R \& D$. Bandung: ALFABETA.

Public Speaking - Pedoman Berbicara Didepan Publik. http://indosdm.com/publicspeaking-pedoman-berbicara-di-depanpublik. 25 Juni 2008 